NBER WORKING PAPER SERIES

\title{
MARKETS AND MULTIUNIT FIRMS FROM AN AMERICAN HISTORICAL PERSPECTIVE
}

\author{
Sukkoo Kim \\ Working Paper 8232 \\ http://www.nber.org/papers/w8232 \\ NATIONAL BUREAU OF ECONOMIC RESEARCH \\ 1050 Massachusetts Avenue \\ Cambridge, MA 02138 \\ April 2001
}

Forthcoming in Joel A.C. Baum and Henrich R. Greve, eds., Multiunit Organization and Multimarket Strategy: Advances in Strategic Management, 2001, Volume 18. Oxford UK: JAI Press. I am grateful to Doug North for the many encouraging and stimulating conversations which led to the ideas presented in this paper. I thank the two editors, Joel Baum and Henrich Greve, for providing many helpful suggestions and constructive editorial advice, and Andrew Godley for his incisive comments on my earlier papers. The views expressed herein are those of the author and not necessarily those of the National Bureau of Economic Research.

(C) 2001 by Sukkoo Kim. All rights reserved. Short sections of text, not to exceed two paragraphs, may be quoted without explicit permission provided that full credit, including $\mathbb{C}$ notice, is given to the source. 
Markets and Multiunit Firms from an American Historical Perspective

Sukkoo Kim

NBER Working Paper No. 8232

April 2001

JEL No. N0, L2

\begin{abstract}
$\underline{\text { ABSTRACT }}$
The expansion of markets and industrialization greatly increased the benefits of specialization in the U.S. economy. However, since the benefits of specialization can only be realized through trade, specialization significantly increases the volume of market transactions in the economy. The analysis presented in this paper suggests that a better understanding of the historical changes in the nature of market transactions costs, especially those related to information, is likely to provide considerable insights on the rise of the modern business enterprise and a richer understanding of the industrial organization of the U.S. economy.
\end{abstract}

Sukkoo Kim

Department of Economics

Washington University in St. Louis

St. Louis, MO 63130

and NBER

soks@wueconc.wustl.edu 


\section{Introduction}

The revolutions in transportation and communications technologies have increased the extent of the U.S. domestic markets over the last two centuries. Moreover, the expansion of markets is associated with major changes in the course of American economic history. The introduction of canals in the late eighteenth and the early nineteenth centuries is credited with increasing the levels of inventive activity and triggering industrialization (Sokoloff, 1988). The extension of markets and industrialization is associated with the growth of Smithian division of labor of all kinds. Households became less self-sufficient and became specialized consumerlaborers; firms that specialized in the production of various goods emerged in great numbers. The division of labor within firms led to a re-organization of production and increased levels of productivity (Sokoloff, 1984a, 1984b). Finally, as regional domestic markets became increasingly integrated between the late nineteenth and the early twentieth centuries, geographic specialization in economic activities increased (Kim, 1995, 1998).

While gains from specialization and trade are likely to be enormous, these gains do not come freely. Specialization increases productivity, but it also leads to greater costs in making transactions (Wallis and North, 1986). Indeed, it is precisely because specialization introduces new costs that specialization will not occur until these additional costs are brought below the benefits of specialization. What kinds of costs does specialization produce? Every trade must overcome two types of costs: transportation and information. Since gains to specialization are realized through trade between agents, specialization increases the volume of goods and people that are transported. Specialization also reduces the information set of the agents. Compared to a more self-sufficient economy, buyers lose information on supply and firms lose information on demand. In addition, specialization exacerbates the problems of asymmetric information. When 
the quality of products is not easily verifiable upon casual observation, firms will know the quality of the products whereas the buyers will not.

This paper argues that the rise and growth of multiunit firms between the late nineteenth and the twentieth centuries are explained by changes in the nature of transaction costs associated with specialization. In the late nineteenth century, due to advances in science and technology, products became more sophisticated and consumers became less and less able to use their senses to identify the quality of the products they consumed. When consumers know less about the quality of products than producers, the conditions are ripe for the classic "lemons" problem where the presence of low quality products drives higher quality products out of the market (Akerlof, 1970). Multiunit firms arose in this environment because they were better able to solve the problem of asymmetric information than the traditional single-unit firms. One important solution to the "lemons" problem is for firms to use advertising and brand-names as a commitment device not to cheat (Klein and Leffler, 1981; Carlton and Perloff, 1994). In this task, the multiunit firms had two significant advantages over single-unit firms: they were able to economize on advertising costs and the sheer size of multiunit firms became a commitment device which credibly signaled to buyers that the cost of reneging was significant.

This paper is organized as follows. Section II will examine the historical relationship between the U.S. domestic market and industrial organizations. Section III will explore the growth of multiunit firms in the twentieth century. Section IV will conclude with a summary.

II. The Evolution of Markets and Industrial Organizations Over American History.

In colonial British North America, the markets for the products of agriculture and extractive industries were well integrated into the British imperial and world economies. 
International transportation costs fell significantly with advances in shipping and the various colonies specialized in the production of goods of their comparative advantages. The northern colonies specialized in sea, wood and grain products and the southern colonies specialized in tobacco, rice, indigo and other extractive industries (Shepherd and Walton, 1972; McCusker and Menard, 1985). In these well developed export markets, the merchants in port cities coordinated the supply of and demand for these products in the world market. On the other hand, the markets for manufactures were small and undeveloped. The population was thinly spread and overland transportation by wagons was prohibitively costly. Given the relatively small market for manufacturing, households manufactured many basic products such as food, clothing and farm implements. It was typical for households to grind their own flour and bake their own bread, make jellies, jams, honey, and maple syrup, brew their own beer, rum and whiskey, and knit various articles of clothing such as mittens and sweaters (Tryon, 1917; Walton and Rockoff, 1998).

In the late eighteenth and the early nineteenth centuries, the expansion of the U.S. domestic markets and industrialization caused a rapid decline in household production and a proliferation of specialized manufacturing firms in the American economy. In this period, the industrial structure was composed of single-unit firms who specialized in the production of manufacturing goods and wholesale merchants and retail store owners who distributed these goods. Since the manufacturing firms typically specialized in a narrow line of products, it was simply too costly for them to market their products directly to consumers. In this setting, the wholesale merchants, who bought and sold sufficient lines of products, were able to lower the costs of transactions more efficiently. The wholesale merchants were not only able to collect 
information on various manufacturers by locating in major cities but were also able to collect information on rural consumer demand through the use of sales agents who traveled to rural country stores (Jones, 1937; Porter and Livesay, 1971; Chandler, 1977). In this period, most consumers were able to judge the quality of most products upon visual inspection. However, for some goods, they relied on the local producers' and retail merchants' reputation for honesty.

In the late nineteenth century, with advances in science and technology, it became increasingly difficult for consumers to discern the quality of products which they consumed. As incomes rose, consumers purchased a growing number of products for which they lacked basic knowledge to discern quality. Moreover, even the manufacturing processes of the most basic of products such as food became so sophisticated that consumers no longer had enough knowledge to discern whether a product was healthy or poisonous. Ellen Richards, one of the figures of the home economics movement, wrote in Food Materials and Their Adulteration in 1885; "We buy everything, and have no idea of the processes by which articles are produced, and have no means of knowing beforehand what the quality may be. Relatively, we are in a state of barbarous innocence, as compared to our grandmothers, about the common articles of daily use (Strasser, 1989, p. 255)."

For many products, it became easier for firms to use the science of chemistry to adulterate or substitute ingredients without the knowledge of consumers. It was widely suspected that firms substituted cane for maple sugar, extended flour and ground coffee with sawdust and chalk fillers, and made blended whiskey from ethyl alcohol, water and coloring (Kallet and Schlink, 1933). In addition, new potentially dangerous preservatives were often used without the consumers' knowledge. Unlike the historic preservatives, such as salt, sugar, vinegar, and wood 
smoke, the new preservatives, such as borax, salicyclic acid and salicylates, sulfurous acids and sulfites, benzoic acids and benzoates, formaldehyde, were without taste or odor in the dosages used. Indeed, Harvey Wiley, the chief chemist of the Department of Agriculture, believed that the most deleterious substance in foods were those added to prevent decay (Young, 1989, p. 151).

The meat packing industry provides an excellent illustration of the emergence of the asymmetric information problem associated with an increasingly specialized economy. In the mid-nineteenth century, given the prohibitive costs of transporting meat prior to the invention of refrigerated cars, the industry was characterized by small, local slaughterhouses. In this setting, the local butchers served a small area and built reputations for the freshness of their meat. As the use of refrigerated cars lowered the costs of transportation in the late nineteenth century, geographic specialization of meat packing increased significantly. Meat packing became concentrated in the Midwest which had considerable comparative advantage in the production of beef (Yeager, 1981; Libecap, 1992). The geographic specialization of the meat packing industry exacerbated the asymmetric information concerning meat. The consumers no longer knew the identity of the butchers who supplied them with their meat. While it may be relatively easy to distinguish fresh versus rotten meat, it was more difficult to verify the claims of the local slaughterhouses that refrigerated meat was butchered under horrible conditions, and that it was diseased and was detrimental to the consumers' health.

Glucose sugar, a product quite different from beef, also came to the forefront of public debate concerning quality of food and drugs. In the late nineteenth century, a growing number of firms began producing glucose sugar manufactured from corn as a substitute for cane sugar. Pure glucose had about two-thirds the sweetening power of cane sugar, but it was much cheaper. Soon 
glucose was used in the making of confectionaries, jellies, canned fruit and meat, and bakery goods. However, numerous individuals, including the cane sugar producers, claimed that glucose sugar was unsafe. Since sulfuric acid and metals were used in the manufacturing process, it was claimed that syrup made from glucose was poisonous as it contained residues of tin, iron, calcium and magnesia. Thus, even though most glucose sugar was safe, it was impossible for consumers to know whether a product was made from glucose sugar and whether it was safe to consume.

"Because of the unfairly bad press glucose had received, argued Frank H. Madden, representing the Wholesale Grocers of Chicago, the public would cease to buy products containing that sweetener should a law be enacted requiring ingredient labeling. At least 98 percent of the 'thinking public,' Madden asserted, deemed glucose 'something vile and unfit for food.' He admitted that 95 percent of the jelly consumed in the nation was made from glucose and the skins and cores of apples, although labeled strawberry or raspberry or whatever other flavor the processor chose to call it. This cheap, wholesome food did not deserve disparaging by physicians and chemists, who were 'always discovering bugaboos,' many of which were merely products of their own imaginations (Young, 1989, p.158)."

The introduction of another basic ingredient in cooking, margarine, raised the public's concern for the potential dangers of food. Patented by a French chemist Hippolyte MègeMouriés, margarine made from animal fat was so close in resemblance to butter that experts and chemists could tell the difference only after extensive tests. When the Chicago meatpackers began to produce margarine or "butterine" in significant quantities, the dairy interests fought back. The butter interests accused margarine, the "midnight assassin," for causing numerous 
deaths. Witnesses testified that margarine was made from the fat of dead horses, dead cows and dead dogs; others argued that diseases such as tuberculosis and trichinosis were transferable to consumers of margarine. In addition, the chemical process, or the use of acids and alkalis, which transformed fat into margarine was claimed to leave poisonous by-products (Young, 1989, pp. 70-94). Once again, even if most margarine was safe, consumers became wary of using it in every day cooking.

If consumers had a difficult time detecting fraud, honest firms had an equally difficult time convincing their customers that their product was of high quality. In this period called the Progressive Era, the asymmetric information problem concerning food and drugs received the most public attention. Moreover, these concerns led to a greater involvement by the federal government with the passages of the Meat Inspection Act of 1891 and the Food and Drug Act of 1906 (Libecap, 1981; Young, 1989). However, the asymmetric information problem was much more general and involved products in many industries. In a wide range of goods from automobiles, tires, and gasolines and basic chemicals such as soaps and new emerging medicines, consumers lacked scientific knowledge to independently judge the quality of these products. In a growing number of industries, the traditional firms faced the "lemons" problem for which they had few answers. In this new technologically sophisticated environment, new firms emerged to solve the growing asymmetric information problem and forged a new industrial structure for the United States.

III. The Rise and Growth of Multiunit Firms in the Twentieth Century

The modern multiunit firms arose in the late nineteenth and the twentieth centuries because they were better able to solve the asymmetric information problem which grew in 
importance over this period. Unlike most single-unit firms, the multiunit firms were able to use advertising and brand-names to credibly signal a certain level of quality of their products to their consumers. In addition, a variety of factors enabled the multiunit firms to use this strategy in this period. Advances in transportation and communications technologies and organizational innovations in advertising lowered the costs of marketing products directly to consumers. Furthermore, the federal government lowered the cost of developing brand names as it provided more secure property rights to a firm's trademarks and passed laws on product quality.

For a growing number of products in this period, the traditional industrial structure composed of single-unit firms in manufacturing, wholesale trade and retail trade was unable to solve the asymmetric information problem efficiently. When the population was dispersed in rural areas, the asymmetric information problem, if it existed at all, was solved largely through the reputation of local producers or retail store owners. For example, the retail store owners were able to develop a level of reputation through repeated, long-term customer relationships. However, as the population became increasingly more concentrated in urban areas, the traditional retail store owners were less able to develop a reputation for honesty. Unlike the traditional general store owner who knew the family histories of his customers, the urban retailers faced a growing number of anonymous shoppers. In this setting, the retailers found it increasingly difficult to find a credible mechanism for signaling honesty.

Klein and Leffler (1981) outlines conditions under which firms will honor their commitments to supply a high level of quality when product quality is difficult to measure. The model assumes that when a firm cheats, the consumers in the market will know that it cheated. In this setting, firms will choose not to cheat if they earn a stream of income from a price that is 
greater than the perfectly competitive price. However, competition will lead firms to make "sunk" non-salvageable firm-specific assets in brand-name that is equal to the rental value of premium quality assuring price. Thus, the model predicts that when asymmetric information is present, firms will make investments in brand name but will also receive higher prices.

Multiunit firms were able to solve the asymmetric information problem through the use of advertising and the development of brand names. In the presence of uncertain quality and the absence of a credible third party enforcer, the main private-contract enforcement mechanism relies on the value of repeat sales to a firm. One solution to signaling a firm's value of repeated sales is to invest in firm-specific and non-salvageable assets such as advertising and developing brand names. Since the value of repeat sales is limited for most single-unit firms, these firms have little incentive to advertise and develop brand names. On the other hand, for multiunit firms, the value of repeat purchase is potentially much greater. Thus, the economies of marketing for multiunit firms come not only from their ability to spread their costs over many plants or stores, but also from the fact that the cost of reneging on their product quality is significantly higher.

In the late nineteenth and early twentieth centuries, various laws passed by the federal government aided in enforcing the private solution to the asymmetric information problem. In the nineteenth century, there was much confusion concerning a firm's legal ownership of trademarks. Once a firm established a brand-name using a certain trademark, many firms imitated the established trademark (Strasser, 1989). In 1905, the Congress passed a trademark law which clarified the legal property rights of trademarks. The new act established that trademarks are legal property under the law and, unlike patents and copyrights, property rights on trademarks did not 
expire. The federal government also became an important third party enforcer with the passage of the Meat Inspection Act of 1891 and the Food and Drugs Act of 1906. If the advances in sciences and technology enabled firms to adulterate foods, it also became possible for scientists employed by the government and non-profit consumer watch dog organizations to verify the claims made by producers (Young, 1989; Rao, 1998). Thus, for both firms and consumers, the federal government and consumer research organizations became important third party agents that could provide independent information on the quality and safety of products.

While the benefits of solving the asymmetric information problem were high, firms could not use the strategy of advertising and developing brand-names until the costs of marketing products fell sufficiently. For most of the nineteenth century, the task of marketing a product directly to consumers at the national level was simply daunting. Since the predominant media of communication was the local newspaper dailies and weeklies, a firm needed to collect information on the cost and benefits of advertising in each of these local newspapers. Given the lack of systematic data on the demographics and the size of readership of any given local newspaper, it was difficult to know what a firm should pay for a particular advertisement. In addition, it was not clear how a manufacturer would monitor whether the advertisements in all these local newspapers were placed honestly and correctly.

Just as the wholesale merchants emerged to coordinate the supply and demand of goods in an earlier era, advertising agencies arose to coordinate the supply and demand of advertisement space in geographically dispersed newspapers and periodicals (Hower, 1949; Pope, 1983.) These agencies collected information on the benefits and costs of placing an advertisement for different types of products, bought space from these newspapers in bulk, and 
then re-sold these spaces in smaller blocks to advertisers. The growth of advertising agencies lowered the costs of marketing sufficiently for a growing number of manufacturers, but the real growth in national advertising by manufacturers did not occur until the rise of national massmedia magazines, radio and television.

In the early twentieth century, the retail multiunit firms, or chain stores, became the first important category of businesses to use the modern method of solving the asymmetric information problem (Lebhar, 1963). Although a growing number of manufacturing firms used advertising and brand-names to signal the quality of their products, it was still too costly for most producers to market their products directly to consumers. For retail chains, as population density increased with urbanization, the cost of marketing multiple stores in a given area fell dramatically. In addition, due to technological innovations such as the rotary steam press, the cost of printing local urban daily and weekly newspapers fell significantly. (See Wegberg and Witteloostuijn, 2001, for an analysis of the impact of new information technologies such as the internet and e-commerce on the structure of the economy.)

The unique data on chain stores collected by the Federal Trade Commission (FTC) in the early 1930s provide unusually rich information on the costs and benefits of marketing products for multiunit retail firms. In May 1928, in order to investigate whether the chain stores violated anti-trust laws, the Senate approved an inquiry by the FTC that collected considerable information on the advantages and disadvantages of chain store distribution. The report took six years to complete and consists of 2,694 pages in four volumes. The FTC sample of firms consists of 1,727 retail chains in 26 lines of retail businesses. These retail chains operated 66,246 stores and sold more than $\$ 5$ billion worth of merchandise and represented about one-half of all stores 
and sales operated by chains in 1928. In addition to collecting basic information on chain stores, the FTC conducted field studies and interviews (Kim 1999b).

The FTC data on chain stores provide considerable evidence that these multiunit retail firms arose to solve the asymmetric information problem by making firm-specific, sunk-cost investments in advertising and brand-names. The data indicate that retail chains like A\&P developed their own private brand labels and advertised extensively to cultivate a reputation for their brands. Unlike the traditional retail stores who bought most of their goods from wholesalers and sold them to consumers in bulk, the retail chains increasingly purchased products directly from manufacturers and sold them as branded items. Moreover, there is considerable anecdotal evidence that many retail chains integrated backward into manufacturing only to preserve their brand identity by ensuring a consistent level of quality of their products.

The FTC data demonstrate that retail chains used private brands to signal quality to their consumers. The data shown in Table 1 indicate that chains with larger numbers of stores were more likely to use private brands. If a chain owned 2 to 5 stores, only 14 percent of these chains carried private brands and, if they owned 51-100 stores, 58 percent carried private brands. However, if the chain owned 1,001 stores or more, 90 percent of the chains used private brands. Table 2 shows the share of private brand sales for grocery chain stores. By 1930, private brand sales accounted for close to 30 percent of total sales and the figure was much higher for the very largest grocery chains.

The advertising data on chain stores suggest that the large multiunit retail firms spent significantly more on advertising than the smaller chain stores. Table 3 shows that, in 1929, if a chain owned 2 to 5 or 6 to 10 stores, it spent an average of $\$ 19,444$ and $\$ 45,051$ in advertising 
respectively. However, for the very large multiunit firms the advertising expenditure was significantly higher. If a chain owned 501 to 1,000 or over 1,000 stores, it spent $\$ 225,000$ and $\$ 1,425,000$ respectively. Thus, the value of firm-specific investments that would be lost by reneging on quality was significantly higher for the larger multiunit firms. In addition, there were significant economies in making this firm-specific investment for chain stores. For the smaller chains, advertising expenditures were about $\$ 6000$ per store; for the very largest chains, they were less than $\$ 400$.

The retail chains were acutely aware that private brands were devices that signaled a certain level of quality to consumers. An A\& P executive noted: "Where the brand A\&P is used, it is employed for the highest quality products which are sold by this company under private label. The A\&P brand never appears on a product having a quality lower than the highest quality we market... At one time the top grade of all our private brands bore the A\&P label. Now we have so-called family groups: A\&P, Quaker Maid, Rajah, Encore, etc., any one of which labels may be on the highest quality of a given product; Rajah, in the case of salad dressing; Quaker Maid in the case of cocoa; Encore, in the case of spaghetti and macaroni; A\&P, in the case of canned peas; Sunnyfield, in the case of flour. The other qualities of these products are under any one of a number of labels. The Iona brand is used for products of standard grade, and the Sultana brand for an intermediate grade, just under the standard set for highest quality. In some cases there is a second intermediate grade also. Thus, in canned peas, the A\&P label designates a very fancy pea - the very best we can buy. Then there are Sultana, Reliable, and Iona peas, each a step further down in grade (Chain Stores, FTC, Vol. 3, 'Chain-Store Private Brands,' p.50-51.)”

However, the retail chain stores faced significant challenges in controlling the quality 
level of their private brands. Many retail chains discovered that wholesale merchants were unreliable in providing products of consistent quality. The growing importance of the asymmetric information problem led to the rise of multiunit retail firms, but it also squeezed out the wholesalers in the distribution channel as retail chains contracted directly with manufacturers. The data in Table 4 indicate that large retail chains purchased most of their private brand items directly from the manufacturers. In some instances, retail chains found that the only way to maintain consistent quality was to produce the goods themselves. While it was costly to integrate backward into manufacturing, it was necessary to maintain the reputation of the brand.

The FTC field interviews of many different types of chain store businesses provide wonderful anecdotal evidence that chain stores manufactured goods mainly due to their concerns on maintaining a consistent quality. A confectionary firm responded: "Our line is not adaptable to wholesale manufactures principally because it does not keep fresh long enough for that purpose. We use butter, fresh cream, and other highly perishable ingredients which make much finer goods but are not suitable for use with the wholesaler's methods of manufacture and distribution." A shoe store manager responded: "Our principal reason and advantage for manufacturing shoes for ourselves is that we are certain to continually keep the standard of construction that we desire. Too often manufacturers who have not the $100 \%$ interest of the retailer at heart will deviate even if only slightly from the standard if necessity compels them to." A drug store manager wrote: "We actually have better chemists and at higher salaries than most manufacturers employ, and we think our merchandise, either ice cream or shaving cream, is of standard that is not surpassed by anybody else. This is very important with things like milk of magnesia and other similar items and we know that our merchandise is very high grade. In other 
words, if your farm out private-brand stuff there is a certain tendency to cut corners and we insist on high quality, not because we are saints but because it is good business."

Finally, a testimony of an apparel chain manager suggests that consumers are uncertain whether a certain type of clothing is fashionable and that the retail chain store builds its reputation on up-to-date style: "Our company is engaged primarily in manufacturing, and the principal reason for our operating our chain of retail stores is to enable us to foresee the consumer demand for styles and colors and to regulate manufacturing accordingly. Through having these chain of retail stores, we are enabled to see from day to day the trend in styles and colors, and through doing this, have been able to effect large savings in our manufacturing operations by not piling up merchandise that is not readily salable; we also sell our merchandise to retailers throughout the country and the experience gained in our own retail shops which, incidentally, are located entirely in metropolitan district with one exception, has enabled us to tell our dealers from time to time the style and color trend (Chain Stores, FTC, Vol. 3, 'Chain-Store Private Brands.' ')"

The FTC data suggest that the retail chains were also able to establish a reputation for lower prices than the single-unit establishments. The FTC collected information on prices of identical products sold by chains and independent stores for groceries and drugs in four cities, Washington DC, Cincinnati, Memphis and Detroit. The data in Table 5 show that in groceries, the chain store prices were lower than that of independent stores by 6 to 10 percent; in drugs, the difference was even larger and ranged between 10 to 20 percent depending upon how one averaged the different products (see also Tedlow's (1996: 201) review of 11 additional studies). The theoretical literature on the use of advertising and brand-names to solve the asymmetric 
information problem on quality do not apply to those on prices. In fact, in the Klein and Leffler (1981) model, firms who commit to higher quality through advertising and branding are able to charge higher prices. Nevertheless, even if the theory is less well developed with respect to prices, the data suggests that multiunit firms also are able to build reputations for lower prices.

Despite the success of urban retail chains, manufacturing firms quickly adopted the multiunit form of organizing production and soon replaced retail chains in importance. Once the costs of marketing fell sufficiently, multiunit manufacturing firms discovered that they were generally more effective in solving the asymmetric information problem than the retail chains. Even though the retail chains were able to develop a certain level of reputation for their private brands through advertising, they faced enormous challenges in maintaining a consistent level of quality. Since manufacturers and wholesalers did not make the same firm specific investments in advertising and private brands, these firms did not have the same incentive for maintaining the proper level of quality as the retail chains. Consequently, there was always an incentive for manufacturers and wholesalers to pass lower quality products onto the retail chains.

Unfortunately, there is little systematic information on the extent to which firms in manufacturing were organized as multiunit firms in the early twentieth century (see Thorp (1924) and Thorp, Crowder et. al (1941)). Nevertheless, there is considerable indirect evidence on their growing importance. One compelling source of information comes from data on advertising expenditures. In the early twentieth century, advertising expenditures grew significantly. Between 1890 and 1929 , advertising expenditures are estimated to have risen from $\$ 190$ million to $\$ 2.987$ billion, or as a percentage of gross national product, from $1.5 \%$ to $2.9 \%$ (Pope, 1983, p.23). There is strong evidence that the growth of advertising expenditures over this period was driven 
by national advertising campaigns of manufacturers. For example, the largest advertisers in national magazines were manufacturers. Of the 58 firms who spent at least $\$ 100,000$ for advertising in major national magazines in any one of the years between 1913 and 1915, the data show that 57 firms were in manufacturing. In addition, the largest advertisers were clustered in a few industries; fourteen in foods, thirteen in automobiles and tires, and nine in chemicals (see Pope $(1983,44-46))$.

In the second half of the twentieth century, with the introduction of the Enterprise Statistics program, the U.S. census bureau began providing census level information on firms. Until this publication, most of the data published by the U.S. census bureau was based on establishments or plants. When the various census programs were established, most firms were single-unit establishments and it was natural for the census bureau to report data categorized at the plant level. However, when firms became multiunit and owned multiple establishments, the traditional census data no longer provided information on firms. In the second half of the twentieth century, when it finally became feasible to coordinate all the censuses to construct data at the firm level of aggregation, the census bureau began reporting this information in its publication called the Enterprise Statistics (see Kim (1999a, 1999b) for more detailed information).

The Enterprise Statistics published between 1954 and 1987 provide the first systematic account of the extent to which economic activity in the United States is organized by multiunit firms. Although most establishments or plants continue to be organized as single-unit firms, the data in Table 6 indicate that multiunit firms accounted for over half of all employees in 1954. Surprisingly, the overall level of multiunit activity has remained relatively constant over the 
second half of the twentieth century. Between 1954 and 1987, the proportion of employment in multiunit activity remained consistently between 50 and 60 percent.

The Enterprise Statistics reports do not provide information on topics such as advertising and the use of national brands by multiunit firms, but they provide considerable indirect information which can be used to examine whether or not they arose to solve the asymmetric information problem. Since products in some industries are more likely to have an asymmetric information problem than in others, the benefits of using advertising and brand-names as devices to signal product quality are likely to differ across industries. Thus, the extent of multiunit activities in different industries may provide interesting clues to whether the costs and benefits of marketing in different industries are likely to explain the industry variations in multiunit activity.

The data on multiunit activity by industries show that the extent of multiunit activity differed significantly across the major sectors of the economy. Table 6 shows that, in 1954, multiunit activity was most important in manufacturing and minerals and least important in services and wholesale trade. In that year, multiunit employment in manufacturing and minerals accounted for 64 and 57 percent of employment in these sectors. In services and wholesale trade, the respective figures were 23 and 27 percent. The figure for retail trade was in between at 39 percent. Except for the mineral industry which fluctuated over time, the importance of multiunit activity grew over the second half of the twentieth century. In manufacturing, the percentage of multiunit employment rose to 77 percent in 1977 but plateaued at that level thereafter. On the other hand, multiunit firms in retail trade, wholesale trade and services steadily grew in importance over this period so that in 1987, 59, 43 and 40 percent of the employment in these respective sectors was organized under these firms. 
The industry data on multiunit firms suggest an interesting hypothesis on the historical changes in the industrial structure of the U.S. economy. In the late nineteenth and the early twentieth centuries, as argued in the previous section, retail chains arose to solve the asymmetric information problem when costs of marketing fell in urban areas. In the first half of the twentieth century, with the introduction of new national media of communications such as the radio and the television, the costs of marketing fell sufficiently for manufacturing firms to use advertising, brand-names and multiunit organization as a mechanism for signaling product quality. In the second half of the twentieth century, as the population became increasingly more mobile, the benefits of establishing brand-names in services increased. Thus, the extent of multiunit activity in the various services increased steadily over the second half of the twentieth century.

The Enterprise Statistics data on industry specialization or diversification by multiunit firms are also likely to provide important information on whether the multiunit firm arose to solve the asymmetric information problem. Since these firms are more likely to develop a reputation for brands for a similar class of products, they are more likely to be organized as horizontal rather than as vertical firms. (See Phillips and Mason, 2001, and Stephan and Boeker, 2001, for alternative analyses of markets which are horizontally connected.) The data in Table 7 show that multiunit firms in most sectors were more specialized than diversified. In 1954, over 75 percent of employment in manufacturing and over 90 percent in minerals, wholesale trade, retail trade, and services were in the same industry at the 3-digit industry level. Although the specialization ratio for most sectors declines over the twentieth century, the ratio remains above 90 percent for the service sectors. In manufacturing, the specialization ratio declines to a low of 58 percent in 1982 before rising to 64 percent in 1987. 
Even in the manufacturing sector, a more careful examination suggests that industry diversification was much lower if one defined products more broadly. In 1958, the Enterprise Statistics reports provide a detailed list of other industry activities by multiunit firms so that a relatively complete picture of diversification can be constructed at various levels of industry aggregation. If one defines industries at the 3-digit industry level, the data indicate that only 13 of 913 -digit industries in manufacturing employed more than 30 percent of their employees in vertical or unrelated industries. However, if horizontal integration is measured by 2-digit rather than 3-digit categories for these 13 industries, the level of diversification falls sharply for many industries except for the integrated petroleum industry (Kim 1999b).

Finally, the data on the number and size of establishments operated by multiunit firms provide additional information on whether these firms arose to solve the asymmetric information problem. If multiunit firms arose to take advantage of economies of marketing rather than those of scale, then there should be little correlation between plant sizes and multiunit firms since there is no relationship between marketing and production technologies. Indeed, Kim (1999a, 1999b) finds that horizontal multiunit firms grew in size predominantly by operating many more establishments rather than by operating plants of large sizes.

The analysis of the rise and growth of multiunit firms presented in this paper differs sharply with that of Alfred Chandler. Chandler in his works, the Visible Hand (1977) and Scale and Scope (1990), argued that the fundamental advantage of the modern multiunit firm is related to production technology rather than its ability to lower market transactions costs. For Chandler, the modern multiunit firm arose to take advantage of economies of speed and flow of throughput (or economies of scale) in production. Since it was necessary for firms to integrate forward into 
distribution to ensure sales of sufficient volume and vertically integrate backwards into raw materials to ensure a constant flow of inputs, the traditional single-unit firms did not have the organizational structure necessary for taking advantage of economies of scale and scope.

Chandler (1977) also provides a narrative history of the evolution of industrial organizations in the United States. In the eighteenth and the nineteenth centuries, when transportation costs were high, traditional single-unit firms produced and distributed goods in the economy. However, as transportation costs fell and markets expanded, modern multiunit firms arose to take advantage of economies of throughput. For Chandler, the multiunit firms arose first in the mass distribution sector because the decline in transportation and communications costs was all that was necessary to take advantage of speed of throughput. However, it required more time for multiunit firms to arise in the manufacturing sector since many basic inventions and innovations in production technology were necessary to achieve economies of scale. Finally, the revolution culminated with the integration of mass production and mass distribution as the modern industrial firms integrated forward into distribution and backward into raw materials.

In contrast, this paper suggests that the modern multiunit firm arose because it was better able to solve the asymmetric information problem concerning the quality and price of products. In the late nineteenth century, with advances in science and technology, consumers no longer possessed sufficient knowledge to judge the quality of the products which they routinely purchased. This paper argues that the multiunit firms arose in this period because they were able to use the strategy of making firm-specific, sunk-cost investments in advertising and branding to credibly earn the trust of consumers on the quality of their products. Since the value of advertising and brand-names is designed to signal the value of repeat sales that is lost if one 
reneged on quality, the large multiunit firms had significant advantages over the traditional single-unit firms.

However, the multiunit firms could not use the strategy of advertising and branding until the costs of marketing fell sufficiently. Since the costs of national marketing was simply too prohibitive in the late nineteenth and the early twentieth century, the multiunit firms first arose in retail trade. As the population became urbanized and as urban newspapers lowered the costs of advertising, retail firms re-organized as multiunit chains and developed private brands to signal product quality. Unfortunately, the urban retailers had a significant problem in maintaining the quality of their branded products since their suppliers did not make the same firm-specific investments in the brand. The wholesalers and manufacturers who sold the products to retailers did not have the same incentive to maintain product quality as specified by a brand. Thus, when the costs of national marketing fell with the introduction of national mass magazines, radio and television, manufacturing firms quickly re-organized as multiunit firms. For many products, the multiunit manufacturing firms discovered that they were more effective in solving the asymmetric information problem than the retail chains.

\section{Conclusion}

Ever since the publication of Adam Smith's Wealth of Nations, scholars have understood the potential benefits of specialization. Yet, given that these benefits can only be achieved through trade, economists, especially in international economics, have also known that specialization introduces new transaction costs, namely transportation costs. Indeed, this is precisely the reason why division of labor is limited by the extent of the market or why specialization is triggered by a decline in transportation costs in the standard models of trade. 
Surprisingly, the idea that specialization introduces transactions costs associated with loss in information has received much less attention. With specialization, consumers know their demands but not the supply conditions of production and firms know their costs but not the demand for their products. While market prices provide valuable information to both buyers and sellers, they are not provided without costs. The existence of the vast array of middlemen who coordinate and facilitate transactions, and the fact that cities arise in part to lower the costs of these transactions, are signs that costs of providing market prices are far from trivial (Wallis and North, 1986; Kim, 2000).

In the late nineteenth and the twentieth centuries, specialization greatly increased the information costs of a different type associated with asymmetric information. In an earlier era, most goods were produced using craft technology that used hand tools and simple machines and were often produced in local homes and small shops. Given the relative simplicity of the production process, consumers could easily discern the quality of the product either through visual inspection or through the reputation of the local producer or retail store owner. In the new era, as production technology became scientifically sophisticated and as goods were produced in factories far from consumers' residences, information became increasingly asymmetric. While firms knew the quality of their products, consumers were less able to use their four senses and knowledge to judge even the most basic of products such as food and household chemicals, let alone the endless variety of new durable consumer goods which emerged over time. In this environment, an increasing number of firms faced the "lemons" problem where lower quality goods tended to out-compete ones of higher quality.

In the early twentieth century, modern multiunit firms emerged in a number of industries 
because they were better able to solve the asymmetric information problem. While the traditional industrial structure composed of specialized single-unit producers, wholesale merchants, and retail store owners was able to efficiently produce and distribute goods when information was dispersed, it was unable to solve the problem of asymmetric information. In a variety of industries, as firms re-organized as multiunit firms to tackle the asymmetric information problem, a new industrial structure emerged. Since the value of repeat sales was significantly higher for multiunit rather than single-unit firms in many industries, the multiunit firms were able make large firm-specific, sunk cost investments in advertising and branding to credibly signal to buyers that the costs of reneging on quality were high. Thus, this paper suggests that a better understanding of the transaction costs associated with specialization, especially those associated with information costs, are likely to shed considerable insights on the rise of multiunit firms and the evolving structure of American industry. 


\section{References}

Akerlof, George A. 1970. 'Market for 'Lemons': Quality Uncertainty and the Market Mechanism," Quarterly Journal of Economics, 84: 488-500.

Carlton, Dennis W. and Perloff, Jeffrey M. 1994. Modern Industrial Organization. $2^{\text {nd }}$ Ed. New York: NY: HarperCollins.

Chandler, Alfred. 1977. The Visible Hand. Cambridge, MA: Belknap Press.

Chandler, Alfred. 1990. Scale and Scope. Cambridge, MA: Belknap Press.

Federal Trade Commission. 1931-1934. Chain Stores. Volumes I-IV. Washington DC: GPO.

Hower, Ralph M. 1949. The History of an Advertising Agency: N.W. Ayer \& Son at Work 18691949. Cambridge, MA: Harvard University Press.

Jones, Fred Mitchell. 1937. Middlemen in the Domestic Trade of the United States 1800-1850. Urbana, IL: University of Illinois.

Kallet, Arthur and Schlink, Frederick. 1933. 100,000,000 Guinea Pigs: Dangers in Foods, Drugs, and Cosmetics. New York, NY: Grosset \& Dunlap.

Kim, Sukkoo. 1995. "Expansion of Markets and the Geographic Distribution of Economic Activities: Trends in U.S. Regional Manufacturing Structure, 1860-1987," Quarterly Journal of Economics 110, 4: 881-908.

Kim, Sukkoo. 1999a."The Rise of Multiunit Firms in U.S. Manufacturing," Explorations in Economic History, 36, 4: 360-386.

Kim, Sukkoo.1999b. "The Growth of Modern Business Enterprises in the Twentieth Century," Research in Economic History, 19: 75-110.

Kim, Sukkoo. 2000. “Urban Development in the United States, 1690-1990," Southern Economic Journal 66, 4: 855-880.

Klein, Benjamin and Leffler, Keith B. 1981. "The Role of Market Forces in Assuring Contractual Performance," Journal of Political Economy 89:615-641. 
Lebhar, Godfrey M. 1963. Chain Stores in America, 1859-1962. Clinton, MA: Colonial Press Inc.

Libecap, Gary D. 1992. "The Rise of the Chicago Packers and the Origins of Meat Inspection and Antitrust," Economic Inquiry 30: 242-262.

McCusker, John J. and Russell R. Menard. 1985. The Economy of the British America, 16071789. Chapel Hill, NC: University of North Carolina Press.

Nelson, Phillip. 1970. "Information and Consumer Behavior," Journal of Political Economy 78: 311-329.

Phillips, Owen R. and Charles F. Mason. 2001. "Collusion in Horizontally Connected Markets: Multimarket Producers as Conduits for Learning." In this volume.

Pope, Daniel. 1983. The Making of Modern Advertising. New York, NY: Basic Books.

Porter, Glenn and Harold C. Livesay. 1971. Merchants and Manufacturers. Chicago, IL: Ivan R. Dee, Inc.

Rao, Hayagreeva. 1998. "Caveat Emptor: The Construction of Nonprofit Consumer Watchdog Organizations," American Journal of Sociology 103: 912-961.

Schmalensee, Richard. 1978. "A Model of Advertising and Product Quality," Journal of Political Economy 86: 485-503.

Shepherd, James F. and Gary M. Walton. 1972. Shipping, Maritime Trade, and the Economic Development of Colonial North America. Cambridge, UK. Cambridge University Press.

Sokoloff, Kenneth L. 1984a. "Investment in Fixed and Working Capital during Early Industrialization: Evidence from U.S. Manufacturing Firms," Journal of Economic History 44: 545-556.

Sokoloff, Kenneth L. 1984b. "Was the Transition from the Artisanal Shop to the NonMechanized Factory Associated with Gains in Efficiency? Evidence from the U.S. Manufacturing Censuses of 1820 and 1850," Explorations in Economic History 21: 351382. 
Sokoloff, Kenneth L. 1988. "Inventive Activity in Early Industrial America: Evidence From Patent Records, 1790-1846," Journal of Economic History 48: 813-849.

Stephan, John and Warren Boeker. 2001. "Getting to Multimarket Competition: How Multimarket Contact Affects Firms' Market Entry Decisions." In this volume.

Strasser, Susan. 1989. Satisfaction Guaranteed. Washington, DC: Smithsonian Institutions Press. Taylor, George. 1951. The Transportation Revolution. Cambridge, MA: Harvard University Press.

Tedlow, Richard S. 1996. New and Improved. Cambridge, MA: Harvard Business School Press. Thorp, Willard. 1924. The Integration of Industrial Operation. Washington, DC: GPO.

Thorp, Willard and W. Crowder, et. al. 1941. The Structure of Industry. Washington, DC: GPO.

Tryon, Rolla M. 1917. Household Manufactures in the United States, 1640-1860. New York, NY: Sentry Press.

U.S. Bureau of the Census, Enterprise Statistics (Washington, DC: G.P.O.), various years.

Wallis, John and Douglass North. 1986. "Measuring the Transaction Sector in the American Economy, 1870-1970." In Long-Term Factors in American Economic Growth, edited by S. Engerman and R. Gallman. Chicago: University of Chicago Press.

Walton, Gary M. and Hugh Rockoff. 1998. History of the American Economy. $8^{\text {th }}$ Ed., New York: NY, Dryden Press.

Wegberg, Marc van and Arjen van Witteloostuijn. 2001. "Strategic Management in the New Economy: Information Technologies and Multicontact Competition." In this volume.

Yeager, Mary. 1981. Competition and Regulation: The Development of Oligopoly in the Meat Packing Industry. Greenwich, CT: JAI Press.

Young, James H. 1989. Pure Food: Securing the Federal Food and Drug Act of 1906. Princeton, NJ: Princeton University Press. 
Table 1

Distribution of Chains Owning Private Brands, 1929-30

\begin{tabular}{lrrll} 
Stores per Chain & Chains & Stores & Chains w/ brands & Stores w/brands \\
\hline 2 to 5 & 886 & 2,901 & $14.2 \%$ & $15.1 \%$ \\
6 to 10 & 323 & 2,412 & 21.4 & 21.4 \\
11 to 25 & 224 & 3,529 & 37.5 & 37.4 \\
26 to 50 & 99 & 3,481 & 44.4 & 46.2 \\
51 to 100 & 57 & 4,236 & 57.9 & 58.5 \\
101 to 500 & 53 & 11,679 & 77.4 & 81.5 \\
501 to 1,000 & 8 & 4,831 & 75.0 & 79.1 \\
1,001 and over & 10 & 32,555 & 90.0 & 76.5 \\
& & & &
\end{tabular}

Source: "Chain Store Advertising," Chain Stores, Federal Trade Commission, 1934.

Table 2

Private Brand Sales for Grocery Chain Stores

$\begin{array}{lrrrl} & \text { Chains } & \text { Stores } & \text { Sales }(\$ 1,000) & \text { Brand Sales } \\ 1919 * & 26 & 1,467 & \$ 127,437 & 18.8 \% \\ 1922^{*} & 57 & 2,133 & 192,631 & 21.3 \\ 1925^{*} & 95 & 3,986 & 377,333 & 27.7 \\ 1928^{*} & 187 & 14,751 & 1,270,128 & 20.4 \\ 1929 * & 255 & 19,754 & 1,815,567 & 28.3 \\ 1930^{*} & 274 & 21,450 & 1,859,311 & 27.9 \\ 1925 & & & & \\ 1928 & 97 & 20,876 & 933,592 & 24.3 \% \\ 1929 & 189 & 35,188 & 2,437,369 & 20.3 \\ 1930 & 257 & 40,748 & 3,140,821 & 24.3 \\ & 276 & 42,353 & 3,177,556 & 24.3\end{array}$

Source: "Chain Store Advertising," Chain Stores, Federal Trade Commission, 1934.

Note: * - Excluding A\&P and Kroger. 
Table 3

Economies in Advertising for Multiunit Firms in Retail Trade, 1928

\begin{tabular}{|c|c|c|c|c|c|c|}
\hline $\begin{array}{l}\text { Stores Per } \\
\text { Chain }\end{array}$ & Chains & $\begin{array}{l}\text { Number of } \\
\text { Stores }\end{array}$ & $\begin{array}{l}\text { Advertising } \\
\text { (\$ mil.) }\end{array}$ & $\begin{array}{l}\text { Advertising } \\
\text { per chain }\end{array}$ & $\begin{array}{l}\text { Advertising } \\
\text { per store }\end{array}$ & $\begin{array}{l}\text { Adv./Sales } \\
\text { (percent) }\end{array}$ \\
\hline 2 to 5 & 792 & 2,595 & $\$ 15.4$ & $\$ 19,444$ & $\$ 5,934$ & $3.57 \%$ \\
\hline 6 to 10 & 293 & 2,179 & 13.2 & 45,051 & 6,058 & 3.74 \\
\hline 11 to 25 & 205 & 3,248 & 6.7 & 32,683 & 2,063 & 2.58 \\
\hline 26 to 50 & 97 & 3,404 & 5.1 & 52,577 & 1,498 & 1.88 \\
\hline 51 to 100 & 55 & 4,052 & 3.9 & 70,909 & 962 & 1.63 \\
\hline 101 to 500 & 48 & 10,600 & 8.1 & 168,750 & 764 & 1.15 \\
\hline 501 to 1000 & 8 & 4,831 & 1.8 & 225,000 & 372 & 0.51 \\
\hline 1,001 and over & 8 & 29,030 & 11.4 & $1,425,000$ & 393 & 0.67 \\
\hline Total & 1,506 & 59,939 & 65.6 & 43,559 & 1,094 & 1.52 \\
\hline
\end{tabular}

\section{Table 4}

Proportion of Merchandise Purchased from Manufacturers by Retail Chain Stores, 1928
(A)
(B)
(C)
(D)
(E)

$\begin{array}{llllll}\begin{array}{l}\text { Stores Per } \\ \text { Chain }\end{array} & \begin{array}{l}\text { Dry Goods \& } \\ \text { Gen Mer. }\end{array} & \text { Grocery } & \begin{array}{l}\text { Drug, Tob., } \\ \text { Hard., Music }\end{array} & \begin{array}{l}\text { Meat, Variety, } \\ \text { Dry Goods }\end{array} & \begin{array}{l}\text { Apparel, Dept. Store, } \\ \text { Furniture }\end{array} \\ \text { 2 to } 5 & 29.4 \% & 27.2 \% & 39.5 \% & 61.2 \% & 83.8 \% \\ 6 \text { to } 10 & 16.9 & 40.6 & 53.8 & 56.0 & 93.5 \\ 11 \text { to } 25 & 25.0 & 35.3 & 76.6 & 70.0 & 92.9 \\ 26 \text { to } 50 & - & 43.2 & 73.0 & 88.4 & 98.7 \\ 51 \text { to } 100 & - & 53.2 & 91.9 & 72.4 & 96.4 \\ 101 \text { to } 500 & - & 54.4 & 77.2 & 89.6 & 95.0 \\ 501 \text { to } 1000 & - & 38.9 & 95.2 & 90.0 & - \\ 1,001 \text { and over } & - & 66.4 & 95.1 & 95.0 & -\end{array}$

Source: "Sources of Chain-Store Merchandise," Chain Stores, Federal Trade Commission, 1934. 
Table 5

Prices of Chain and Independent Distributors

\begin{tabular}{lcccl} 
& \multicolumn{2}{c}{ Groceries } & \multicolumn{2}{c}{ Drugs } \\
& Independents & Chains & Independents & Chains \\
Washington DC & $\$ 58.03$ & $\$ 54.08$ & $\$ 130.09$ & $\$ 117.49$ \\
Cincinnati & 23.35 & 21.95 & 143.34 & 130.54 \\
Memphis & 38.11 & 35.96 & 119.17 & 106.02 \\
Detroit & 35.66 & 33.26 & 144.73 & 129.67
\end{tabular}

Groceries

Unweighted Geometric Avg

$7.3 \%$

6.4

6.0

7.2
$6.4 \%$

8.8

8.3

10.5
Drugs

$\begin{array}{ll}\text { Unweighted } & \text { Geometric Average } \\ 10.7 \% & 22.7 \% \\ 9.8 & 20.4 \\ 12.4 & 20.7 \\ 11.6 & 17.5\end{array}$

Source: "Chain Store Advertising," Chain Stores, Federal Trade Commission, 1934.

Note: Prices cannot be compared across cities. The bundle of goods used to compare prices of chains and independents differ across cities. In groceries, the number of items used is as follows: DC, 274; Cincinnati, 120; Memphis, 193; Detroit, 183. In drugs, they are: DC, 226; Cincinnati, 268; Memphis, 212; Detroit, 256. 
Table 6

The Share of Employment in Multiunit Firms, 1954-1987

$$
\begin{array}{llllllll}
1954 & 1958 & 1963 & 1967 & 1972 & 1977 & 1982 & 1987
\end{array}
$$

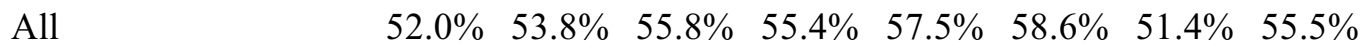

$\begin{array}{lllllllll}\text { Minerals } & 57.2 & 56.7 & 51.9 & 58.1 & 67.3 & 64.6 & 55.5 & 55.5\end{array}$

$\begin{array}{lllllllll}\text { Construction } & - & - & - & 17.0 & 21.5 & 24.6 & 23.7 & 16.9\end{array}$

$\begin{array}{lllllllll}\text { Manufacturing } & 64.4 & 67.4 & 70.0 & 74.5 & 77.4 & 77.9 & 77.0 & 76.2\end{array}$

$\begin{array}{lllllllll}\text { Public warehouse } & 24.7 & 34.6 & 30.0 & - & - & - & - & -\end{array}$

$\begin{array}{lllllllll}\text { Wholesale trade } & 26.8 & 29.8 & 29.3 & 32.4 & 35.1 & 39.8 & 39.4 & 43.1\end{array}$

$\begin{array}{lllllllll}\text { Retail trade } & 38.7 & 40.2 & 43.0 & 44.4 & 49.9 & 51.6 & 53.3 & 58.8\end{array}$

$\begin{array}{lllllllll}\text { Services } & 23.4 & 27.5 & 29.0 & 30.1 & 36.0 & 37.1 & - & 40.3\end{array}$

Sources: Enterprise Statistics, 1954-1987.

Table 7

The Share of Employment of Multiunit Firms in Same Industries, 1954-1987

$\begin{array}{lcccccccc}\text { All } & 84.7 \% & 84.0 \% & 80.2 \% & 78.9 \% & 77.1 \% & 76.9 \% & 79.8 \% & 83.0 \% \\ \text { Minerals } & 90.9 & 85.3 & 84.6 & 83.0 & 73.2 & 73.7 & 76.9 & 79.9 \\ \text { Construction } & - & - & - & 96.4 & 94.9 & 93.4 & 93.0 & 95.8 \\ \text { Manufacturing } & 77.3 & 75.8 & 70.2 & 65.4 & 60.8 & 60.2 & 58.0 & 63.8 \\ \text { Public warehouse } & 98.3 & 93.0 & 96.3 & - & - & - & - & - \\ \text { Wholesale trade } & 95.4 & 96.6 & 95.3 & 93.8 & 93.0 & 91.0 & 90.3 & 90.0 \\ \text { Retail trade } & 94.5 & 93.4 & 91.4 & 90.2 & 88.4 & 88.1 & 88.1 & 89.4 \\ \text { Services } & 98.3 & 97.4 & 95.8 & 96.2 & 94.0 & 93.6 & - & 93.9 \\ & & & & & & & & \end{array}$

Sources: Enterprise Statistics, 1954-1987. 